\title{
STRATEGIC PLANNING OF INFORMATION SYSTEMS AND INFORMATION TECHNOLOGY IN PT. $X$
}

\begin{abstract}
Chandra Kusuma Putra Harijono ${ }^{1}$, Erma Suryani ${ }^{2}$
${ }^{1}$ S.Kom, Master of Technology Management, Sepuluh Nopember Institute of Technology, Surabaya, Indonesia ${ }^{2}$ S.T., M.T., Phd, Master of Technology Management, Sepuluh Nopember Institute of Technology, Surabaya, Indonesia

Abstract

PT. X is one of the companies that provide a point of sales solution in Surabaya. PT. X have already used IS/IT for their business support but not fully support the business operation at PT. X. No integration between user computer and lack of experienced staff to maintain and develop the current IS/IT made PT. X lacking the knowledge about IS/IT. The problem above made the IS/IT from PT. X not keeping up with the company's aim and business target. This problem could decrease the business quality of PT. X. From the description above, a strategic planning for IS/IT will be conducted in PT. X. this research cover company internal and external condition analysis, both in term of business and technology, company SWOT analysis, future needs interpretation using Value Chain Analysis, Critical Success Factor and Balanced Score Card. The expected result from this research is a guide to arrange IS/IT and business strategy along with providing a future application portfolio that could support the business in accordance with the business strategy of PT. X.
\end{abstract}

Keywords: IS/IT Strategic Planning. Value Chain Analysis, Ward \& Peppard Methods, Criticial Success Factor and Balanced Scorecard

\section{INTRODUCTION}

In this growing age of technology, the usage of information system/information technology in a company is one of many factors that could help the company to grow and compete in the business world. With the implementation of IS/IT in a company could boost the effectiveness and efficiency of the company operational work. For the IS/IT to go in tune with the business strategy and maximally support the work, then the IS/IT in a company must be design and built according the business situation of the company.

PT.X have already implemented IS/IT to support their business process, but still looks so standard, there are no developments with the right planning in progress. Many mistakes happen when the company hold a procurement for their hardware and network so many mistake happen in funds management and network implementation. This issue caused hardware and software update rarely done, and decrease the staff performance who worked at the company and the after sales service quality for the existing client.

The IS/IT development done in PT. X, just to solve this time problems and need, PT. X doesn't think of the business condition that could happen in the future so the development only done for this time only. The limitation of resource from
PT. $\mathrm{X}$ in running the business process also becomes a problem.

PT. X does not have guidelines and policies governing the conduct of IS / IT investment and later will set the hardware, software and networks needs in the future. PT. X also does not have a staff of experts to study the situation and condition of IS / IT used by the company and do not have picture of the IS / IT needed to improve the quality of service of PT. $X$ in the future.

From the conditions explained above a strategic planning of IS / IT for PT. X required and is projected over the next five years. a direction for PT. X in the development of information systems and information technology that will support the business objectives of the institution is expected with the strategic planning of information systems and information technology.

\subsection{Relationship between Business Strategy, IS Strategy and IT Strategy}

From Figure 1.1 it can be concluded that the company should treat IS/IT as part of the business like marketing, production or purchase, which must be carried out effectively and efficiently to business survival, but also can provide a sense of competitive and strategic for the company if managed intelligently. 
This implies an approach to developing strategies for information systems and technology derived from and integrated with other components of the business strategy.

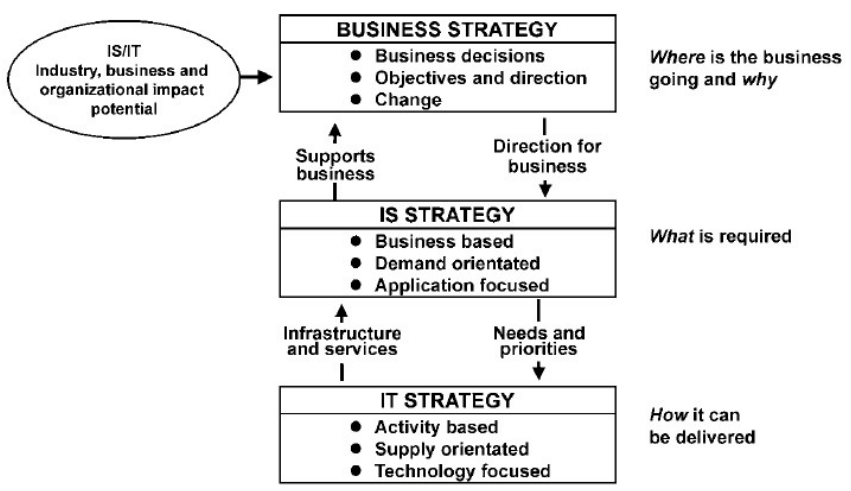

Fig 1. 1 Relationship between Business Strategy, IS Strategy and IT Strategy

If the company develops the marketing division as part of a business strategy, it should be analyzed first is the marketing position. After evaluating the marketing needs and the options available in relation to other needs. The diagram shows the same thing to be treated in the field of IS/IT. Identifying the potential impact first, and then evaluate the information and systems needed to provide a strategy and determine the best way to get the information system using existing technology. The model may be too simple to handle complex business quickly based on environmental changes. But it can be a good starting point to clarify the relationship between the problems encountered.

One of the methodologies used in the strategic planning of IS/IT is a methodology version of Ward and Peppard. Figure 1.2 shows a model of strategic planning / IT Ward and Peppard.

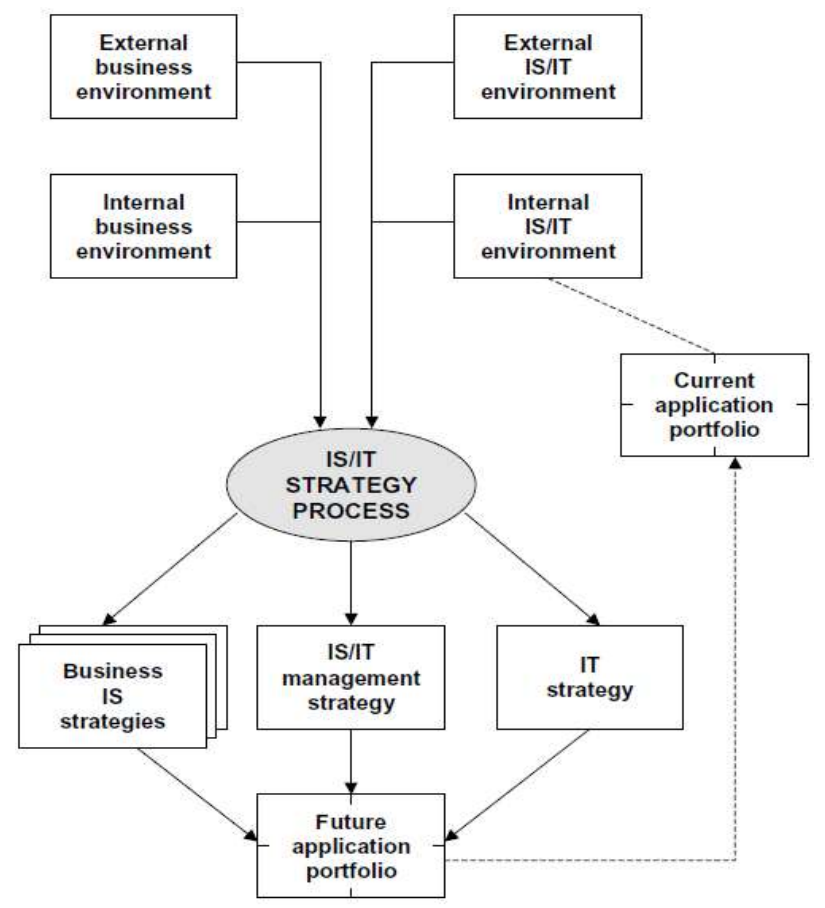

Fig 1. 2 Strategic Model IS/IT

\subsection{Strategic Planning Information Systems and} Information Technology

Planning a strategy of IS / IT is defined strategic thinking and planning for long-term management of effective and optimal impact of information in all its forms: Information Systems (IS) and Information Technology (IT) system combines manual and computer, computer and telecommunications technology. It also includes aspectsof management organization IS/IT. Quick but somewhat narrow definition offered by Lederer and Sethi is a "Process of deciding goal for computing the organization and identify potential computer applications that organizations should be implemented."

\subsection{Balanced Scorecard}

Balanced Scorecard (BSC) is an analysis method to carry out management strategies as well management strategy implementation. Implementation of $\mathrm{BSC}$ can produce two major reports, the strategy map and scorecard. BSC consists of four perspectives, namely:

1. Financial perspective

2. Customer perspective

3. Internal process perspective

4. Learning and growth perspective

Expected BSC can produce a strategic plan that has the characteristics kompherensif, coherent, balanced and measured.

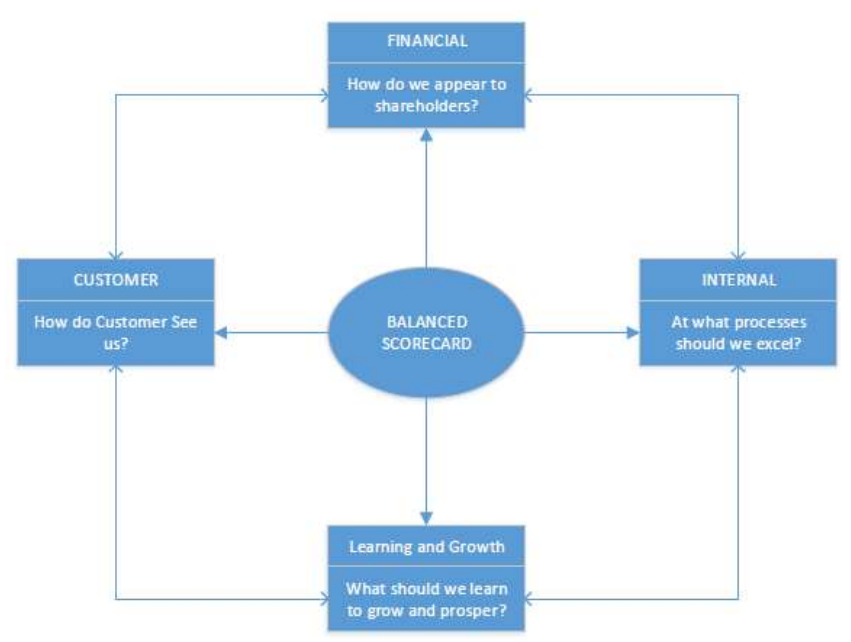

Fig 1.3 Balanced Scorecard

\subsection{Critical Success Factor}

According to Ward and Peppard, CSF analysis is a restricted area in a business which, if fulfilled, will ensure success for the company's competitive performance (Ward \&Peppard, 2002). Meanwhile, according to Rockart, as cited by Ward and Peppard defining critical success factors (CSFs) as a specific area within the company, which, if satisfactory results of the area will ensure the company's success in competing. That area is the key where something should go well and correctly, so that business success can be achieved and 
continue to grow (Ward \&Peppard, 2002). Some of the benefits of CSF analysis are as follows:

1. Analysis of the CSF is the most effective technique in engaging senior management in developing information systems strategy. Because the CSF as a whole has its roots in the business and provide a commitment for top management in using information systems that are aligned with the achievement of corporate goals through critical business area.

2. Analysis of CSF connect SI project to be implemented with the aim, so the information system will be realized in line with its business strategy.

3. In interviews with senior managers, CSF analysis can be a good intermediary in knowing what information is required each individual.

4. By providing a link with information requirements, CSF analysis plays an important role in prioritizing capital investment potential.

5. Analysis of CSF is very useful in the planning system at the time the information is not consistent business strategy consistent with the objectives of the company, focusing on specific issues are most critical.

6. Analysis of CSF is very useful when used in conjunction with value chain analysis to identify the most critical processes, and focuses on achieving goals through activities that are most appropriate to be implemented. The process of critical success factors (CSFs) can be seen in Figure 1.4. CSFs determination can only be made when the company's business objectives have been identified.

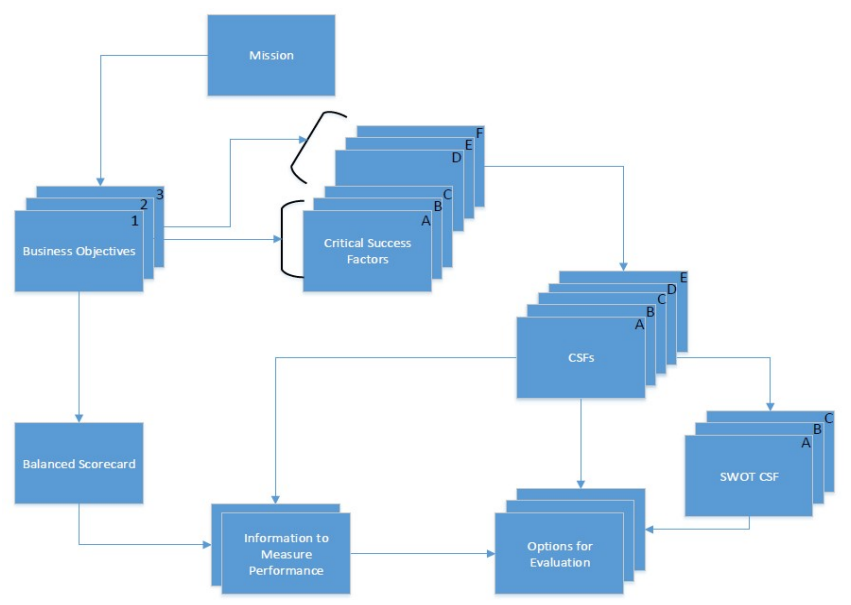

Fig 1.4 Critical Success Factor

\subsection{BSC-CSF Consolidation}

According to (Ward \&Peppard, 2002), the output of the Balanced Scorecard analysis and CSF analysis can be combined to provide for a more comprehensive information system. Balanced scorecad measure the objectivity of the business while the CSF identifies the most critical things to achieve that result. The combination of both these analyzes help improve operational activities and identifying the internalexternal information needed by the operational activities and measure performance related to business performance and business goals.

\section{METHODOLOGY}

In this chapter will discuss the research methods for the strategic planning of IS/IT with methods Ward and Peppard (2002). This paper, requires a relatively complete information data as a material that supports the truth and accuracy of the data.

\subsection{Preliminary Stage}

At this stage it will be explained about the problems faced by PT. X.The background of this research, the research goal and benefit both from the perspective of business and academic will also be explained in this stage

\subsection{Collecting Data and Information Stage}

In conducting the research data and information relating to the object of research is necessary. To meet this need, then at this stage will be filled with activity literature studies, interviews, studies of corporate documents, and observation.

First is the literature studies, research without basic science or the theoretical basis cannot be validated and verified the truth, therefore, a literature studies is needed to add knowledge in conducting research. The literature used is related to the research literature.

The literature used is obtained from various sources, including books, journals, books previous thesis and other literature sources relevant to research conducted

Second is the Corporate Documents study, Corporate documents study is needed to get the data and information that will be researched

Third is Observation, Observation activities conducted through direct observation to obtain business processes in the company. In addition to knowing the application of information systems and infrastructure that have been used by the company.

And fourth is Interview with the company stakeholder, interview is one of several ways to collect information, interviews are typically used to collect information about the internal state of the company's current and expected in the future. The interview was conducted directly by the owners, marketing managers and IT managers associated with the operational management of IT enterprise and business management of the company. 


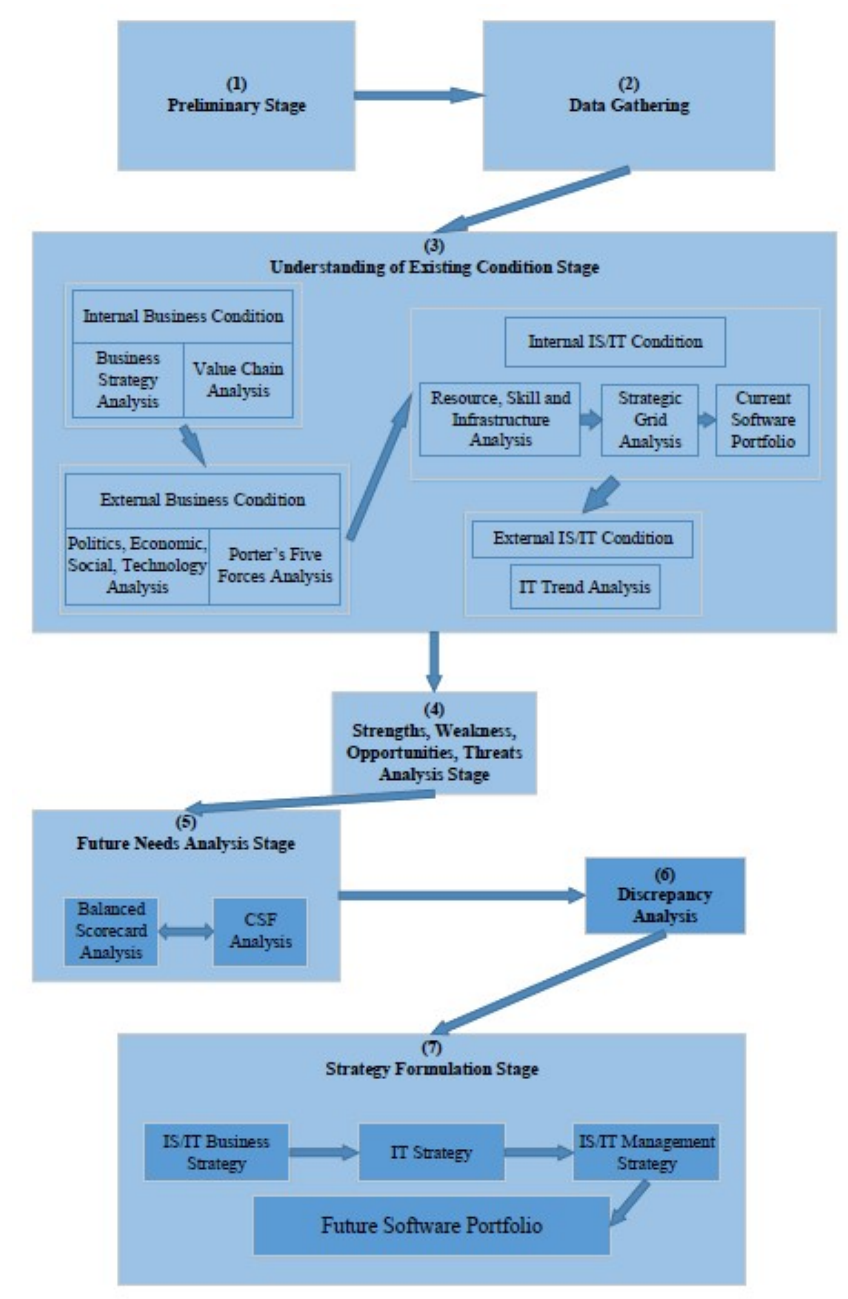

\subsection{Understanding of Existing Condition Stage}

This stage aims to determine the current conditions that exist in the company, both in terms of business environment and SI / IT companies. Activities undertaken at this stage is to analyze the internal environment of business, business external environment, internal environment of SI / IT and external environment SI / IT in the company. Each of these analyzes were performed using different techniques, tailored to the needs analysis conducted. There are several things that will be analyzed in this stage. First, Internal Business Condition, this condition will be analyzed using strategy business analysis and value chain analysis. Second, External Business Condition, this condition will be analyzed using Politics, Economics, Social and Technology (PEST) Analysis along with Porter's Five Forces analysis. Third, the Internal IS/IT Condition, this condition will be analyzed using Resource, Skill and Infrastructure analysis and current software portfolio analysis, current software portfolio analysis will be mapped into four different part, strategic, high potential, operational or support. The next analysis will be external IS/IT Condition, this condition will be analyzed using IT Trend analysis, IT Trend analysis will only analyze the technology used in the same industry with PT. X which is retail.

\subsection{Future Needs Analysis Stage}

This section will analyze the needs of the IS / IT of the company in the future. To be able to describe the conditions that will come, a Balance Scorecard analysis will be performed to identify the needs of potential business in the future, and analyzed using a critical success factor for identifying the needs of its information systems.

\subsection{Strategy Formulation Stage}

This chapter will explain the formulation of strategies based on the results of the previous analysis, the expected output is the IS business strategy, management strategy SI / IT and IT strategy and future software portfolio.

First, SI business strategy formulation and advice on the application required by PT. X in the future to meet the business objectives to be achieved. This strategy was implemented to improve the business activities of PT. X.

Second, IT strategy formulation contains a policy strategy for the management of technology and expertise. This strategy is applied to produce recommendations that support the IT needs of application proposals PT. X.

Third, Formulation of management strategies / IT unbiased policy on the maintenance of the infrastructure in terms of technology, namely hardware and software company in accordance with the limits of available funds. This strategy applied to be an added value to the organization and management of infrastructure services to the community level.

\subsection{Determination Future Portfolio Application}

\section{Stage}

This stage will produce applications that could be developed or used by PT. X to support their business process. Procurement applications must be planned and managed in accordance with their contribution to the organization at this time and in the future which will then be mapped using McFarlan Strategic Grid. The application portfolio is generated from three of strategy formulation in the previous Stage, formulation of SI business strategy, IT strategy and management strategy of IS / IT.

\section{CONCLUSION}

PT. X in running the business tend to use technology as needed and below standard, never do strategic planning in advance so that management does not know the full potential of the use of SI / IT was there today. shortage of employees with knowledge of the technology also causes PT. $X$ tends to be slow in following the development of the IS / IT that exist today. strategic recommendations for PT. X not as an end but a process to later development into better and can meet the needs of business in accordance with the vision of the company 
which is a become the best point of sales solution distributor in Indonesia that prioritizes comfort of the client. All analysis starts from the analysis of internal and external factors, to the formulation of strategies to produce a portfolio of applications that could be developed by the company to achieve the vision of the company.

Results of formulation strategies that have been written can help enterprises to improve competitiveness in the company. Business strategy IS can be used to enhance the company's capability in the field of information systems and the expansion of marketing network, for IT strategy is used to support the needs of the information system used in the company, the management strategy of IS / IT can help companies to retain the use of information systems and information technology implemented to support the business processes and the application portfolio can be a guideline for the company to expand market reach and increase the comfort of a regular customer of the company.

\section{REFERENCES}

[1] David, F.R (2013). Strategic Management: Concepts and Cases $\left(14^{\text {th }}\right.$ ed.). Florence, South Carolina: Pearson.

[2] Long, Yuan, et al (2003), Enterprise-wide Strategic Information Systems Planning for Shanghai Bell Corportaion. Annals of Cases on Information Technology, 5.

[3] Curry, Joanne; Ferguson, Jeff (2000), Increasing the Success of the Global Information Technology Strategic Planning Process, Proceedings of the $33^{\text {rd }}$ Hawaii International Conference on System Sciences.

[4] Jaana, Mirou; Teitelbaum, Mari; Roffey, Tyson (2012), IT Strategic Planning in a Pediatric Hospital: Overview of the Process and Outcomes, $45^{\text {th }}$ Hawaii International Conference on System Sciences.

[5] R. Hevner, Alan; Studnicki, James (2000), Strategic Information Systems Planning with Box Structures, Proceedings of the $33^{\text {rd }}$ Hawaii International Conference on System Sciences.

[6] Lv, Zhe (2010), Case Study: Strategic Information Systems Planning in Shanghai Key Universitities in Yangpu District, International Conference on eEducation, e-Business, e-Management and e-Learning.

[7] McKay, Judith; Marshall, Peter; and Smith, Lisa, "Steps towards effective IT governance: strategic IS planning, evaluation and benefits management" (2003). PACIS 2003 Proceedings. Paper 65.

[8] Earl, M. (1989). Management Strategic for Information Technology. Sidney: Prentice Hall.

[9] Fredrickson, D. C. (2005). Are you sure you have a strategy? Academy of Management Executive, 19(4).

[10] Hunger, \&Weelen. (2004). Strategic Management and Business Policy. Jersey: Prentice Hall.

[11] Porter, M. E. (1991). Towards a Dynamic Theory of Strategy. Strategic Management Journal, 12, 95-117.
[12] Porter, M. E. (2008, January). The Five Competitive Forces That Shape Strategy. Harvard Business Review, $1-17$.

[13] Rangkuti, F. (2001). Creating Effective Marketing Plan. Jakarta: GramediaPustakaUtama.

[14] Robson, W. (1997). Strategic Management \& Information Systems ( $2^{\text {nd }}$ ed.). London: Prentice Hall.

[15] Ward, J., \&Peppard, J. (2002). Strategic Planning for Information Systems ( $3^{\text {rd }}$ ed.). Bedfordshire, United Kingd om: John Wiley \& Sons, Ltd.

[16] Luftman, Jerry (2000), 'Assessing Business-IT Alignment Maturity', Communications of Association for Information Systems: Vol. 4, Article 14

[17] Teubner, A., Mocker, M. et al. (2010), 'Information Systems Strategy: Reconceptualization, Measurement, and Implications', MIS Quarterly Volume 34 Issue 2, June 2010, Pages 233-259 